$\begin{array}{cccc}\text { S sciendo } & \text { International Conference KNOWLEDGE-BASED ORGANIZATION } \\ \text { Vol. XXV } & \text { No 2 } & 2019\end{array}$

\title{
THE IMPACT OF CORRUPTION ON THE BUSINESS IN BULGARIA AND ROMANIA
}

\author{
Vladislav KRASTEV, Blagovesta KOYUNDZHIYSKA-DAVIDKOVA, \\ Irina ATANASOVA
}

\author{
"Neofit Rilski" South-West University, Blagoevgrad, Bulgaria \\ vladislav_swu@abv.bg; vesi_8808@abv.bg; irina_atanasova@yahoo.com
}

\begin{abstract}
Nowadays, the topic of corruption is extremely relevant, not only in terms of clarifying its nature and appearance, but also in terms of its impact on business development. Corruption as a phenomenon goes through constant changes from the past to the present. Its growing significance from a resource redistribution tool to a regulator of social mechanisms, plays the role of a risk factor for the economic development of each country. In this context, the role of corruption is crucial for the business. Its importance in the economic and business climate, on one hand limits the input of foreign capital investment and on other hand slows the development of the companies, leading to an incorrect redistribution of their assets. As a result, there are significant losses for the business, as well as there is a disturbance of the economic cycle of the country. At the same time, business is an area predisposed to corruption. There are numerous possibilities for committing crimes and unethical behavior in this area. It is therefore necessary to analyze the impact of corruption on business development. In this regard, the aim of this report is to make a comparative analysis of the impact of corruption on the business in Bulgaria and Romania.
\end{abstract}

\section{Keywords: business, corruption, Bulgaria, Romania}

\section{Introduction}

The Government of the Republic of Bulgaria is facing a number of challenges related to the protection of the state and the public interest. Creating the right balance between them is a challenge for any modern and developing country, especially when it is necessary to create sustainable policies against the phenomenon corruption. On one hand for the economic development is needed a policy in compliance with the processes of globalization and on the other the economic development depends exclusively on business initiatives. Moreover, in the context of high dynamics of the business environment, the constantly increasing competition and the globalization, an active condition for the development of a country's economy is the activity of the entrepreneurial business on the market [1].

Corruption is a phenomenon that dates back to the time when the first power structures are formed [2]. The opinions of economists about the nature of corruption is gradually changing. Initially it is believed that corruption, although morally reprehensible, in practice often facilitates the exchange of goods and the cash flow. This contributes to the economic growth [3]. While other authors suggest the opposite, that corruption is dysfunctional to the economy, as it reduces the level of confidence among market players. This in turn, leads to 
increased insecurity of transactions and harms the entire economy [4]. According to Pukala and Adamisin it even affects the family budget [5]. In addition, Gordon Tullock, which generally has a negative opinion on the issue of corruption recognizes that it can play a positive role. He points out that corruption can be defined as an add-on to the low salaries of the officials, which in turn is a motivation for more flexible and entrepreneurial actions [6].

Of a great interest is the opinion of Bukowski on the phenomenon of corruption. According to him, the business takes the view that corruption on a smaller scale have been long accepted as a way of doing business and in many countries it is a typical tool for a reaching a deal [7]. Moreover, many businesses seek innovative ways to improve efficiency and maintain a a competitive advantage to survive [8]. However, it requires the development of various techniques to improve business competitiveness [9]. In addition, it is necessary to bear in mind that an important tool for the business in the competitive struggle, to build competitive advantages and to increase competitiveness is the innovation potential [10].

The literature review shows considerable interest from various authors to clarify the nature of corruption, the relationship between corruption and business, as well as its impact on the business development. It is influenced by the crucial importance of the role of corruption on the business development. Regardless of how corruption is perceived, it is an undeniable fact that it is one of the most important phenomenon for the development of the business. In this connection, it is necessary, according to us society and businesses to have a clear idea of what constitutes corruption and its impact on the business as well.

\section{Analysis and Discussion}

Corruption is important for business development. It is therefore necessary to analyze its level. This can be achieved by using the so-called Corruption Perceptions Index (CPI) introduced in 1995 by Transparency International [11]. It measures the level of political and administrative corruption in a given country, as perceived by the business analysts from around the world, including experts interviewed by the surveyed countries. The value of the CPI varies from 100 , which is indicative of a low level of corruption to 0 - an indicator of high level of corruption. Values below 50 are indicative of the existence of serious problems in combating corruption in each country. In this regard, Table 1 presents the values of the Corruption Perceptions Index of Bulgaria and Romania in the period 2012-2018.

Table 1 Corruption Perceptions Index

\begin{tabular}{|c|c|c|c|c|c|c|c|}
\hline \multirow{2}{*}{ Country } & \multicolumn{7}{|c|}{ Corruption Perceptions Index } \\
\cline { 2 - 8 } & 2012 & 2013 & 2014 & 2015 & 2016 & 2017 & 2018 \\
\hline \multirow{2}{*}{ Bulgaria } & 41 & 41 & 43 & 41 & 41 & 43 & 42 \\
\hline Romania & 44 & 43 & 43 & 46 & 48 & 48 & 47 \\
\hline
\end{tabular}

Source: Authors' annual report of Transparency International

The data in Table 1 show that for the analyzed period Corruption Perceptions Index in Bulgaria is lower than in Romania.
The exception is 2014 where its value is the same for both countries - 43 points. It is note worthy that the Corruption Perceptions 
Index in Romania reached 48 points in 2016 and 2017 years. For Bulgaria its value was highest in 2014 and 2017 years and it is 43 points. However, it is necessary to emphasize that in both Bulgaria and Romania, the values of the Corruption Perceptions Index remained below 50 points. This in turn is indicative of a systemic problem in combating corruption.

An important aspect of this report is the opinion of the business representatives about the level of corruption in Bulgaria and Romania. Based on results published in reports of the Flash Eurobarometer in 2013 [12], 2015 [13] and 2017 [14] year, a comparative analysis of the impact of corruption on the business in these two countries is made. This survey focuses on issues relating to problems encountered in the process of doing business.

According to a survey of Flash Eurobarometer 374 "Businesses' attitudes towards corruption in the EU" for 2013, the main problems the business face are:

- in terms of tax rates - $81 \%$ of the respondents in Romania consider that tax rates are enormous problem in doing business in the country and in Bulgaria almost half of respondents (42\%) point out the same;

- in terms of rapidly changing laws and policies - $88 \%$ of business representatives in Romania indicate that the rapidly changing laws and policies are a serious problem in doing business, while in Bulgaria significantly smaller proportion are those who claim the same $(59 \%)$;

- in terms of complexity of administrative procedures - there is almost equal share of respondents - $82 \%$ (Romania) and $81 \%$ (Bulgaria) pointing out that the complexity of administrative procedures is a comprehensive problem for the business;
- regarding the lack of resources or procedures for debt collection - here roughly equal is the proportion of respondents - 70\% (Romania) and 67\% (Bulgaria), indicating that the lack of resources or procedures to collect debts due to them is a major problem in doing business;

- in terms of access to finance, including loans - $62 \%$ of respondents in Romania consider that access to finance is an outstanding problem in doing business in the country and in Bulgaria almost half of respondents (44\%) show the same;

- regarding the restrictive provisions of the labor law - 61\% of business representatives in Romania indicate that the restrictive provisions of labor law are a serious problem in doing business, while in Bulgaria significantly smaller proportion of the representatives say the same $(43 \%)$;

- in terms of inadequate infrastructure in the country - a significant share of the business representatives in Romania $(84 \%)$ point out that the inadequate infrastructure is a major problem in businesses and in Bulgaria this share is just over half $(52 \%)$;

- regarding the level of corruption - in Romania, $65 \%$ of respondents indicate that corruption is a major problem in doing business. In Bulgaria, less than half of the surveyed $(51 \%)$ considered the same;

- in terms of patronage and nepotism - a relatively equal share of business representatives point out that these are a serious problem in business; for Romania this share is $64 \%$ and Bulgaria $-60 \%$.

Regarding the respondents' answers in 2015 and 2017 relating to the above mentioned problems, the results are presented in Table 2. 


\begin{tabular}{|c|c|c|c|c|c|c|c|c|c|c|c|c|}
\hline \multirow{3}{*}{$\begin{array}{l}\text { Problems encountered } \\
\text { when doing business }\end{array}$} & \multicolumn{6}{|c|}{ Results for 2015 (in \%) } & \multicolumn{6}{|c|}{ Results for 2017 (in \%) } \\
\hline & \multicolumn{3}{|c|}{ Bulgaria } & \multicolumn{3}{|c|}{ Romania } & \multicolumn{3}{|c|}{ Bulgaria } & \multicolumn{3}{|c|}{ Romania } \\
\hline & $\begin{array}{l}\text { A very } \\
\text { serious } \\
\text { problem }\end{array}$ & $\begin{array}{c}\text { Not a } \\
\text { problem }\end{array}$ & $\begin{array}{l}\text { I do } \\
\text { not } \\
\text { know }\end{array}$ & $\begin{array}{l}\text { A very } \\
\text { serious } \\
\text { problem }\end{array}$ & $\begin{array}{c}\text { Not a } \\
\text { problem }\end{array}$ & $\begin{array}{c}\text { Ido } \\
\text { not } \\
\text { know }\end{array}$ & $\begin{array}{l}\text { A very } \\
\text { serious } \\
\text { problem }\end{array}$ & $\begin{array}{c}\text { Not a } \\
\text { problem }\end{array}$ & $\begin{array}{c}\text { Ido } \\
\text { not } \\
\text { know }\end{array}$ & $\begin{array}{l}\text { A very } \\
\text { serious } \\
\text { problem }\end{array}$ & $\begin{array}{l}\text { Not a } \\
\text { problem }\end{array}$ & $\begin{array}{l}\text { Ido } \\
\text { not } \\
\text { know }\end{array}$ \\
\hline $\begin{array}{l}\text { 1. Regarding to the tax } \\
\text { rates }\end{array}$ & 40 & 59 & 1 & 80 & 18 & 2 & 31 & 66 & 3 & 78 & 20 & 2 \\
\hline $\begin{array}{l}\text { 2. Regarding the rapidly } \\
\text { changing laws and } \\
\text { policies }\end{array}$ & 69 & 27 & 4 & 85 & 13 & 2 & 65 & 34 & 1 & 82 & 16 & 2 \\
\hline $\begin{array}{l}\text { 3. Regarding the } \\
\text { complexity of } \\
\text { administrative procedures }\end{array}$ & 78 & 20 & 2 & 79 & 18 & 3 & 72 & 26 & 2 & 86 & 11 & 3 \\
\hline $\begin{array}{l}\text { 4. Regarding to the lack } \\
\text { of funds or procedures for } \\
\text { debt collection }\end{array}$ & 70 & 28 & 2 & 71 & 25 & 4 & 68 & 29 & 3 & 73 & 23 & 4 \\
\hline $\begin{array}{l}\text { 5. Regarding to the access } \\
\text { to financing, including } \\
\text { loans }\end{array}$ & 41 & 55 & 4 & 56 & 36 & 8 & 25 & 69 & 6 & 69 & 26 & 5 \\
\hline $\begin{array}{l}\text { 6. Regarding to the } \\
\text { restrictive provisions of } \\
\text { labor law }\end{array}$ & 45 & 48 & 7 & 63 & 31 & 6 & 47 & 43 & 10 & 70 & 27 & 3 \\
\hline $\begin{array}{l}\text { 7. Regarding to the } \\
\text { inadequate infrastructure } \\
\text { in (our country) }\end{array}$ & 60 & 39 & 1 & 82 & 17 & 1 & 62 & 37 & 1 & 93 & 4 & 3 \\
\hline $\begin{array}{l}\text { 8. Regarding to the level } \\
\text { of corruption }\end{array}$ & 61 & 35 & 4 & 74 & 25 & 1 & 62 & 35 & 3 & 85 & 10 & 5 \\
\hline $\begin{array}{l}\text { 9. Regarding to the } \\
\text { patronage and the } \\
\text { nepotism }\end{array}$ & 67 & 31 & 2 & 70 & 27 & 3 & 58 & 39 & 3 & 82 & 14 & 4 \\
\hline
\end{tabular}

Source: Table, compiled by the authors on the report of Flash Eurobarometer

The data in Table 2 show that in 2015, for business representatives from Romania, the largest proportion is those, who consider as the most serious problem in doing business the rapidly changing legislation and policies $(85 \%)$. Regarding the respondents' answers for 2017, the results show that the most significant problem in business is in terms of complexity of administrative procedures - 86\%. However, for the respondents from Bulgaria, the largest proportion are those who point out as the most serious problem in doing business is the complexity of administrative procedures $(78 \%)$. It is obvious that for 2017, the respondents in Bulgaria identify as the most significant problem in business the same as in 2015 . For not so significant problem in Romania in 2015 is determined the access to finance and in Bulgaria - the tax rates. The results for 2017 demonstrate that for both Romania and Bulgaria it is not so serious the problem concerning the access to financing, including loans.

Another important aspect of the problem of corruption is how widespread is it according to business representatives in different countries. Data from the reports of Flash Eurobarometer, years - 2013, 2015 and 2017 for Bulgaria and Romania show the following:

- for 2013 - 91\% of respondents in Romania consider that the level of corruption is very widespread; in Bulgaria the proportion is slightly lower - 89\%;

- for 2015 - almost all of the respondents in Romania (95\%) indicate that the level of corruption is very widespread, which is observed in respondents from Bulgaria as well - 91\%;

- for 2017 - the answers to the business community in Romania show that $96 \%$ of them consider the level of corruption very widespread, while in Bulgaria the percentage is $89 \%$.

Of a great interest is the issue for the most common corruption practices. In this regard, based on the reports of the Flash Eurobarometer the following is concluded:

- for 2013 - as the most widespread corrupt practice in Romania the respondents consider the "favoritism to friends and family members in public institutions" (42\%), and as least widespread - "giving kickbacks". In Bulgaria respondents considered the most widespread corrupt practice "tax fraud or evasion of VAT (Value-Added Tax)" (36\%), and as least widespread 
"offering free gifts or travelling in exchange for a service" (11\%);

- for 2015 - 39\% of respondents in Romania indicated with an equal share as the most widespread corrupt practices "funding of political parties in exchange for public contracts or influence on the policy making" and "bribery". As least widespread corrupt practice is stated "giving kickbacks" (19\%). Regarding Bulgaria, $40 \%$ of respondents, and in 2013 point out as the most applied practice "tax fraud or evasion of VAT (Value-Added Tax)", and at least applied as in 2013 "offering free gifts or travelling in exchange for a service" $(14 \%)$;

- for 2017 - "bribery" is defined as the most common corrupt practice in Romania (54\%), and as least popular "offer of a free gift or travel in exchange for a service" $(16 \%)$. The most common corrupt practice in Bulgaria is considered "the financing of political parties in exchange for public contracts or influence on the policy making" (47\%), and at least popular, as well as in 2013 and 2015 "offer of a free gift or travelling in exchange for a service " $(14 \%)$.

\section{Conclusions}

The presented results on the impact of corruption on business development in Bulgaria and Romania show that in both countries there are serious problems in combating corruption. It is concluded that the value of the index of perception of corruption in Bulgaria and Romania are unsatisfactory. The major problems, which the business faces are: the set tax rates, the rapidly changing laws and policies, the complexity of administrative procedures, the lack of resources or procedures for debt collection, the access to finance, including loans, the restrictive regulations of labor legislation, the inadequate infrastructure in the country, the level of corruption, the patronage and the cronyism. It is observed that the level of corruption in Bulgaria and Romania is very widespread. The most common corrupt practices in Bulgaria are "tax fraud or evasion of VAT" and "the financing of political parties in exchange for public contracts or influence on the policy making", and in Romania "favoritism to friends and family members in public institutions", "financing of political parties in exchange for public contracts or influence on policy making" and "bribery".

In conclusion, we believe that it is necessary to emphasize that corruption is a global problem that on one hand should become a major subject of discussion in global political forums and on the other - of adequate response of the leading political and economic factors.

\section{References}

[1] Kyurova, V., Marketing in the entrepreneurship activity, Blagoevgrad: Neofit Rilski, p. 5, 2014.

[2] Bielecki, Z., Fenomenkorupcji-diagnoza, "PrzegladPolicyjny", No. 2, Szczytno, 2002.

[3] Lui, F.T, Three Aspects of Corruption, Contemporary Economic Policy, Vol. 14, No. 3, 1996.

[4] Treisman, D., The Causes of Corruption: A Cross-National Study, Journal of Public Economics, Vol. 76, 2000.

[5] Pukala, R., Adamisin, P., Unit-linked life insurances where the investment risk is borne by the policy holder as an element of shaping household savings portfolios in Poland after the accession to the European Union, European Financial Systems 2015 of the 12th International Scientific Conference, Masaryk Faculty of Economic and Administration Department and Institute for Financial Market, June 18-19, Brno, Czech Republic, pp. 458-465, 2015. 
[6] Tullock, G., Corruption Theory and Practice, Contemporary Economic Policy, Vol. 14, 1996.

[7] Bukowski, J., Lockheed-największelapówkiświata, Warszawa, 1978.

[8] Petrova, M., Tepavicharova, M., \& Dikova, L., Possibilities for human capital development in the mining and quarrying sector in Bulgaria, E3S Web of Conferences, Vol. 41, 04017 IIMS, Kemerovo, Russian Federation, 2018.

[9] Petrova, M., Buzko, I., \& Dyachenko, Yu., Cognitive, Intelligence Technologies and Economical Foundations of Teaching of International Economical Relations and Tourism, 17th International Scientific Conference ERDev, Jelgava, Latvia, pp. 11021106, 2018.

[10] Kyurova, V., Research on the impact of the innovation potential on the competitiveness of furniture enterprises, Entrepreneurship, Vol. 2, p. 199, 2015, http:// ep.swu.bg/ images/ pdfarticles/ 2015pdf/ RESEARCH $\%$ 20ON\% 20THE\% 20IMPACT $\% 20 \mathrm{OF} \%$ 20THE\% 20INNOVATION\%20POTENTIAL\%20ON.pdf.

[11] Corruption Perceptions Index, available at: https: // www.transparency.org/ research/cpi/ overview.

[12] Flash Eurobarometer 374, Businesses 'attitudes towards corruption in the EU, 20132014.

[13] Flash Eurobarometer 428, Businesses 'attitudes towards corruption in the EU, 2015.

[14] Flash Eurobarometer 457, Businesses 'attitudes towards corruption in the EU, 2017. 